\title{
The risk of craniofacial traumas while working with animals
}

\author{
Praca ze zwierzętami a ryzyko urazu twarzoczaszki
}

\author{
Joanna Bilska-Stokłosa ${ }^{1, A-D \oplus}$, Michał Marcinkowski ${ }^{1, B-C \oplus}$, Krzysztof Osmola ${ }^{1, E \oplus,}$ \\ Hanna Tomczak ${ }^{2, D, F} \odot$ \\ ${ }^{1}$ Department of Maxillofacial Surgery, Heliodor Święcicki Clinical Hospital, University of Medical Science Poznań, Poland \\ ${ }^{2}$ Central Microbiology Laboratory, H. Swiecicki Clinical Hospital, University of Medical Sciences, Poznań, Poland \\ A - Research concept and design, B - Collection and/or assembly of data, C - Data analysis and interpretation, \\ $D$ - Writing the article, E - Critical revision of the article, F- Final approval of the article
}

Bilska-Stokłosa J, Marcinkowski M, Osmola K, Tomczak H. The risk of craniofacial traumas while working with animals. Med Srod. 2021; 24(1-4): 30-33. doi: $10.26444 / \mathrm{ms} / 145356$

\section{Abstract}

Introduction and Objective. Viscerocranial fractures may have different aetiology. Injuries in agriculture, both those related to typical farm work and those caused by animals, are also important. The aim of this study was to analyse the causes and types of craniofacial fractures in patients who were treated for injuries suffered at work related to animal husbandry. Materials and method. The study was conducted on patients of the Maxillofacial Surgery Department, Poznań University of Medical Sciences, Poland, who were hospitalised between 1 January 2014 and 31 December 2019. The study was conducted only on patients with extensive craniofacial injuries, which are a significant clinical problem, require surgical treatment, and involve the highest risk of complications.

Results. Between 1 January 2014 and 31 December 201917 patients with extensive injuries related to animal husbandry were hospitalised at the Department and Clinic of Maxillofacial Surgery, Poznań University of Medical Sciences. The patients suffered animal-induced craniofacial fractures - two of them fell off a horse, the other fifteen were kicked by an ungulate animal. Seven patients suffered fractures in the middle level of the face: the zygomatic bone, the maxilla, and the orbital bones. These were the most common injuries. Six patients had fractures in the lower level of the face (mandibular fractures only). Two patients suffered injuries in both the middle and lower level of the face.

Conclusions. Injuries induced by large animals are relatively rare. Most of the patients analysed in our study suffered their injuries as a result of being kicked by a horse, which mostly inflicted fractures of the middle level of the face. Craniofacial injuries may cause serious complications due to the anatomical and functional complexity of this part of the human body.

\section{Key words}

craniofacial fractures, animal, injury

\section{Streszczenie}

Wprowadzenie i cel pracy. Złamania twarzoczaszki mogą mieć różną etiologię. Nie bez znaczenia są również urazy, jakich doznają osoby zatrudnione w rolnictwie, zarówno te związane z typową pracą rolniczą, jak i te spowodowane przez zwierzęta.

Celem pracy była analiza przyczyn i rodzajów złamań twarzoczaszki u pacjentów leczonych z powodu urazów doznanych w pracy związanej z hodowlą zwierząt.

Materiał i metody. Badaniem objęto pacjentów Kliniki Chirurgii Szczękowo-Twarzowej Uniwersytetu Medycznego w Poznaniu, hospitalizowanych w okresie od 1 stycznia 2014 do 31 grudnia 2019 roku. Przeprowadzono je wyłącznie na pacjentach z rozległymi urazami twarzoczaszki, które stanowią istotny problem kliniczny, wymagają leczenia chirurgicznego i wiążą się z największym ryzykiem powikłań.

Wyniki. W okresie od 1 stycznia 2014 do 31 grudnia 2019 roku w Katedrze i Klinice Chirurgii Szczękowo-Twarzowej Uniwersytetu Medycznego w Poznaniu hospitalizowano 17 osób z rozległymi urazami związanymi z hodowlą zwierząt. Pacjenci doznali złamań twarzoczaszki spowodowanych przez zwierzęta - dwóch z nich spadło z konia, pozostałych piętnastu kopnęło zwierzę kopytne. Siedmiu pacjentów doznało złamań w środkowej części twarzy: kości jarzmowej, szczęki i oczodołu. To były najczęstsze urazy. Sześciu pacjentów miało złamania w dolnej części twarzy (tylko złamania żuchwy). Dwóch pacjentów doznało urazów zarówno na środkowym, jak i dolnym poziomie twarzy.

Wnioski. Urazy spowodowane przez duże zwierzęta są stosunkowo rzadkie. Większość pacjentów objętych naszym badaniem doznała urazów w wyniku kopnięcia przez konia, których efektem w większości było złamanie środkowego poziomu twarzy. Urazy twarzoczaszki mogą powodować poważne komplikacje ze względu na złożoność anatomiczną i funkcjonalną tej części ciała.

\section{Słowa kluczowe}

złamania twarzoczaszki, zwierzę, uraz

\section{INTRODUCTION}

Address for correspondence: Joanna Bilska-Stokłosa, Department of Maxillofacial Surgery, Heliodor Święcicki Clinical Hospital. Poznan University of Medical Sciences, Poznań, Poland

E-mail: assia_bi@interia.pl

Received: 15.12.2021; accepted: 27.12.2021;
The issue of craniocerebral injuries is dealt with by doctors of various specialisations. Craniofacial injuries may cause serious complications due to the anatomical and functional 
complexity of this part of the human body. The aesthetic aspects of facial injuries are equally important, especially in the context of social life and interpersonal relations. Viscerocranial fractures may have different aetiology. Researchers list traffic accidents and beatings as the most frequent causes of these fractures. Injuries in agriculture, both those related to typical farm work and those caused by animals, are also important.

According to Accidents at Work in 2018, published by the Central Statistical Office in Gdańsk in 2019, in the previous year there were 723 work accidents related to farming, animal husbandry and breeding, and hunting, including 5 fatalities [1]. According to the report of the Agricultural Social Insurance Fund (KRUS), in 2019 there were 13,641 accidents, including 57 fatalities [2]. Most of the casualties suffered injuries by falling $(4,975)$, being caught or hit by moving parts of machines and devices $(1,222)$, and by being hit, crushed or bitten by animals $(1,236)$.

\section{OBJECTIVE}

The aim of this study was to analyse the causes and types of craniofacial fractures in patients of the Clinical Department of Maxillofacial Surgery at the University of Medical Sciences in Poznań, Poland, who were treated for injuries sustained at work related to animal husbandry. Patients practising horse riding were excluded from the analysis.

\section{MATERIALS AND METHOD}

The study was conducted on patients of the Maxillofacial Surgery Department, Heliodor Święcicki Clinical Hospital, at the University of Medical Sciences in Poznań, Poland, who were hospitalised between 1 January 2014 - 31 December 2019. The study involved analysis of the available medical documentation of treatments administered to inpatients (with special focus on medical history, physical examination, and operative reports) and outpatients at the Maxillofacial Surgery Clinic at the University of Medical Sciences in Poznań. The patients' radiology documentation with both preoperative and postoperative X-ray images was analysed. The study was conducted only on patients with extensive craniofacial injuries, which are a significant clinical problem, require surgical treatment, and involve the highest risk of complications.

\section{RESULTS}

Between 1 January 2014 - 31 December 2019, 17 patients with extensive injuries related to animal husbandry were hospitalised at the Department and Clinic of Maxillofacial Surger of Poznań University of Medical Sciences. There were 13 men and 4 women in this group. The youngest patient was 16 -years-old and the oldest was 63 -years-old. The patients' average age was about 40 .

The patients suffered animal-induced craniofacial fractures - two of them fell off a horse, the other fifteen were kicked by an ungulate animal (Tab. 1). Nine patients were kicked while transporting a horse, five were kicked by a bull, and one was kicked while milking a cow. All patients
Table 1. Craniofacial fractures characteristics

\begin{tabular}{lcccccc}
\hline & $\begin{array}{c}\text { Orbitozy- } \\
\text { gomatic } \\
\text { fracture }\end{array}$ & $\begin{array}{c}\text { Orbitomaxil- } \\
\text { lozygomatic } \\
\text { fracture }\end{array}$ & $\begin{array}{c}\text { Man- } \\
\text { dibular } \\
\text { fracture }\end{array}$ & $\begin{array}{c}\text { Orbitozygo- } \\
\text { matic and } \\
\text { mandibular } \\
\text { fractures }\end{array}$ & $\begin{array}{c}\text { Fronto- } \\
\text { orbital } \\
\text { fracture }\end{array}$ & $\begin{array}{c}\text { Fronto-or- } \\
\text { bito-nasal } \\
\text { fracture }\end{array}$ \\
\hline Horse & 2 & 4 & 2 & 1 & 1 & 1 \\
\hline Bull & 1 & 0 & 3 & 1 & 0 & 0 \\
\hline Cow & 0 & 0 & 1 & 0 & 0 & 0 \\
\hline
\end{tabular}

suffered isolated head injuries. None of them had multiple injuries.

Seven patients suffered fractures in the middle level of the face: the zygomatic bone, the maxilla, and the orbital bones. These were the most common injuries. Six patients had fractures in the lower level of the face (mandibular fractures only) (Fig.1). Two patients suffered injuries in both the middle and lower level of the face. Two patients had extensive fractures in the upper level of the face - a frontoorbito-nasal fracture and a fronto-orbital fracture (Fig. 2). Bone injuries were accompanied by soft tissue injuries, such as contused wounds, haematomas, and livedos. There was one case of an extensive fronto-orbito-nasal fracture with damage to the patient's eyeball, which required its enucleation (Fig. 3).

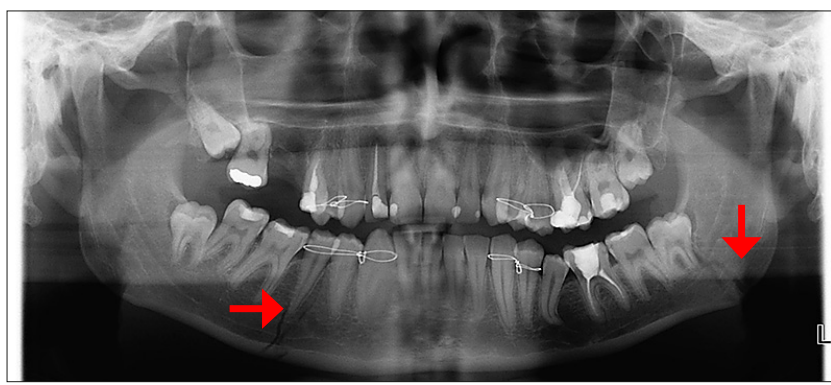

Figure 1. Panoramic radiograph showing a double mandibular fracture. The red arrows indicate the sites of fractures

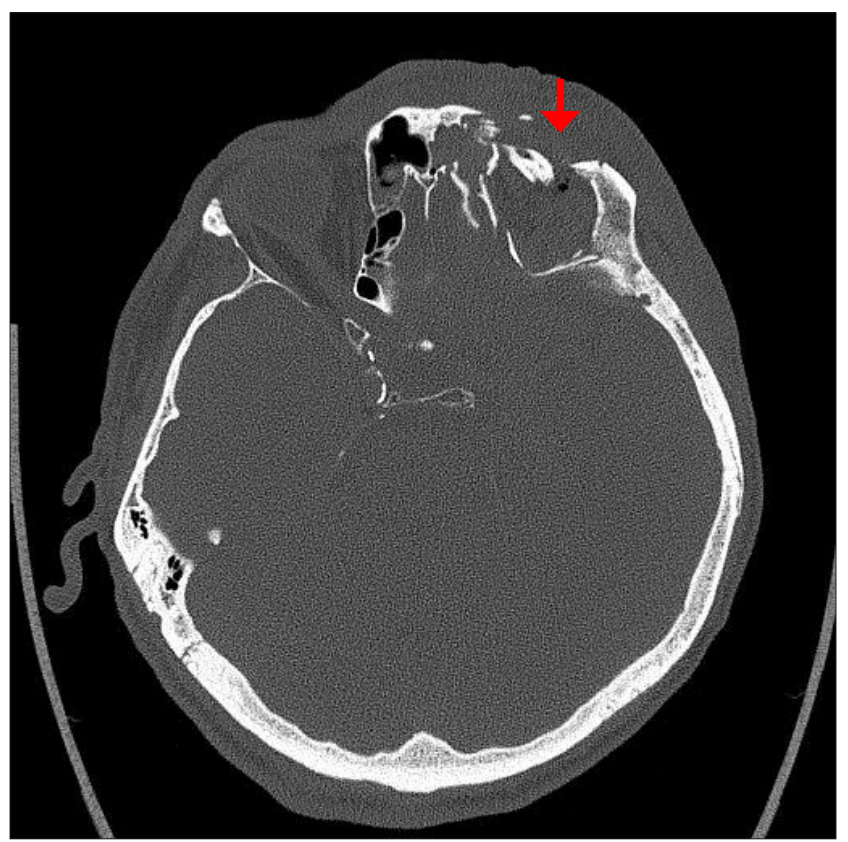

Figure 2. A computed tomography scan - axial projections. Comminuted fractures of the left squamous part of the frontal bone, the roof and the medial wall of the left orbit, together with the upper edge of the orbit and the base of the anterior cranial fossa (red arrow) 


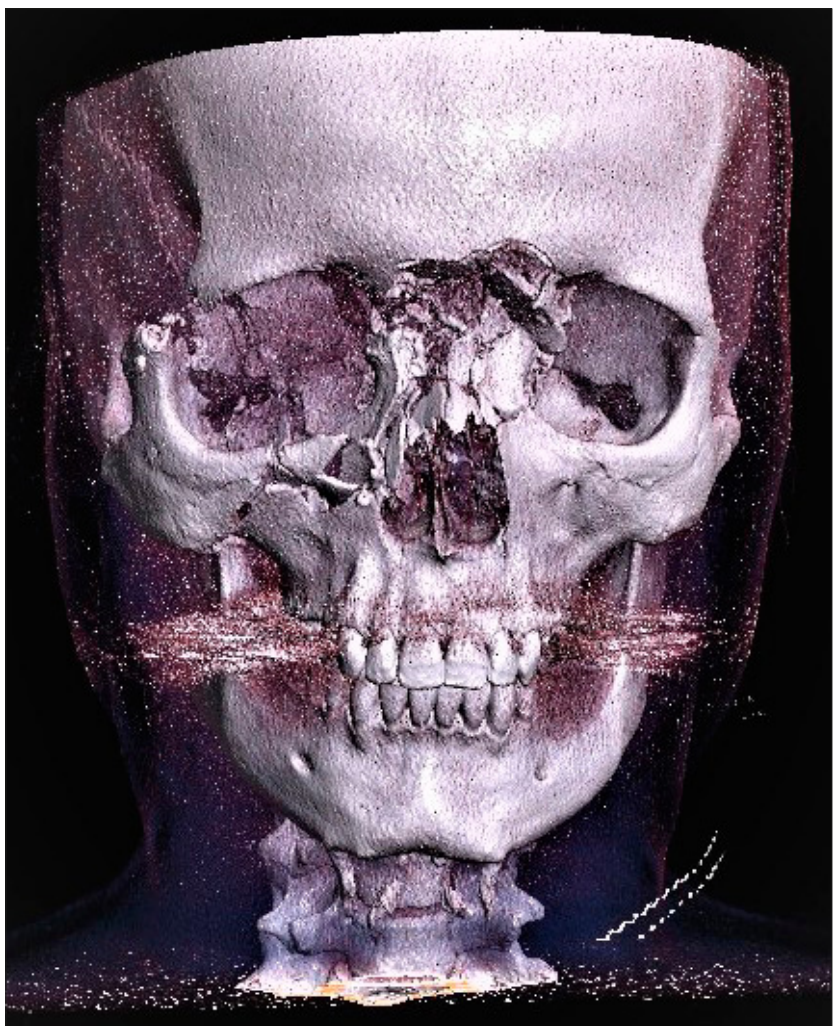

Figure 3. A computed tomography scan $-3 D$ reconstruction. Comminuted fractures of the upper and middle levels of the face

Four patients admitted they had consumed alcohol immediately before starting the work during which the accident occurred. None of the patients wore any protective gear at work. All the patients were qualified for surgical treatment to have the bone fragments repositioned and stabilised under general anaesthesia and antibiotic cover. After the bones had been repositioned, they were stabilised with dedicated titanium micro- and mini-plates (Fig. 4 and 5).

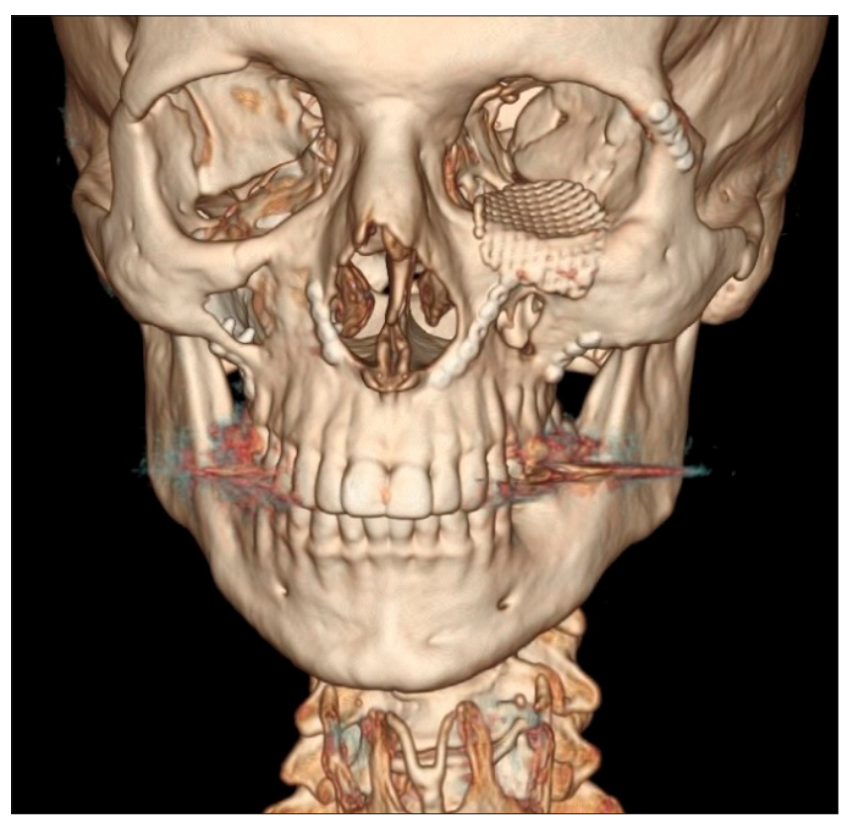

Figure 4. A computed tomography scan - 3D reconstruction. The patient after the stable osteosynthesis of the displacement of the upper part of the face. There are titanium microplates and a mesh reconstructing the fracture of the inferior wall of the left orbit

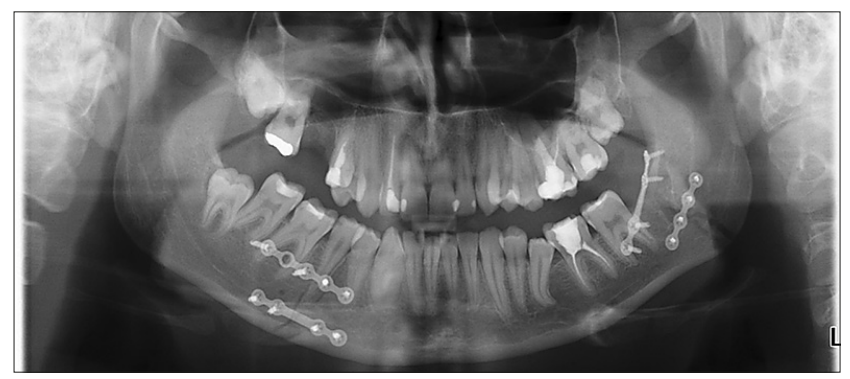

Figure 5. A panoramic radiograph showing the patient after the stable osteosynthesis of a double mandibular fracture. There are titanium miniplates in the mandible

On average, the patients stayed in hospital for 7.3 days, which is consistent with other researchers' reports [3]. The long-term observation did not reveal any complications in the healing of either soft tissue injuries or craniofacial fractures.

\section{DISCUSSION}

Injuries induced by large animals are relatively rare [4]. Due to the weight and speed of animals, they can induce serious traumas which are similar to injuries suffered in traffic accidents [5]. Most of the patients analysed in this study suffered their injuries as a result of being kicked by a horse, which mostly inflicted fractures of the middle level of the face. Islam et al. [6] also observed that zygomaticomaxillary complex fractures were the most common. Fractures of the anterior and posterior walls of the frontal sinus, ethmoid cells, and orbital bones are some of the most severe maxillofacial injuries. The most common causes of these fractures are collisions with motor vehicles, road accidents, and interpersonal violence. There have been very few reports on these fractures being caused by horse kicks [7]. Due to the vicinity of the eyeball, injuries in this area not only significantly affect the face aesthetics, but they may also cause functional disorders or permanent visual impairment.

One of the patients analysed in the current study was kicked by a horse and suffered an extensive eye injury. This resulted in visual impairment and the need to enucleate the patient's eyeball. The surgical treatment of craniofacial fractures consists in bone repositioning and stabilisation with titanium mini- and micro-plates and screws. These procedures were applied in the cases analysed in this study. There were no bone healing complications. The patients in the current study did not develop any wound infections, although these circumstances involved the risk of significant contamination of soft tissue injuries. The duration of hospitalisation significantly affects the risk of infection. Our patients were discharged from hospital fairly quickly, so their operative wounds were not infected with the hospital microflora. Patients may also be infected with their own microflora. Most infections are caused by Staphylococcus aureus. On admission to hospital the patients in this study were tested for pathogenic microorganisms - MRSA, VRE, strains producing carbapenemases. These tests are part of perioperative prophylaxis in our hospital, which prevents infections $[9,10]$. Antibiotics are administered in accordance with the procedures applied before surgery involving the implantation of a foreign body to avoid biofilm-related infections. Beta-lactams and clindamycin are used in our 
antibiotic prophylaxis procedures. These antibiotics kill both the aerobic and anaerobic microflora.

As no signs of infection were observed in our patients' wounds, no material for microbiological tests was collected. The patients came to our hospital fairly quickly after the accident, so their wounds were not colonised by pathogenic microflora. As there were no cases of bites, our patients had no contact with animals' saliva. They suffered injuries by being kicked, therefore it was important to take contact with soil into account and the possibility of infection with Clostridium tetani [8]. Before the patients were admitted to hospital, they had received first aid in the admission rooms of other hospitals, where they had been interviewed about potential vaccinations or the administration of anti-tetanus immunoglobulin. There they had their wounds pre-cleansed to accelerate healing. Accidents caused by animal kicking usually occur in the countryside, where access to hospital is difficult. The patients described in the current study received professional medical help fairly quickly, which influenced the healing process. Rabies is another problem related with accidents induced by animals. However, this disease is usually carried by wild animals and stray dogs, whereas our patients did not suffer injuries from them.

Four of the patients analysed in this study had worked under the influence of alcohol, which may have caused the animals' aggression. There are no scientific publications describing this aspect, but it may be an important factor influencing animals' behaviour. Therefore, further observations are necessary to investigate this issue. Young people should be properly educated and trained before they start working with animals.

\section{CONCLUSIONS}

1. Injuries induced by large animals are relatively rare. Most of the patients analysed in our study suffered their injuries as a result of being kicked by a horse, which mostly inflicted fractures of the middle level of the face.

2. Examination of patients at the entrance to the hospital for the carrier of multidrug-resistant strains ensures an appropriate selection of antibiotics used in periprocedural prophylaxis, which minimizes nosocomial infections in operated patients.

3. The importance should be emphasized of promptly referring the patient to a specialist centre for surgery in order to prevent colonization associated with long-term hospitalization, which has a huge impact on the effects of quick recovery after surgery, without complications related to hospital infections.

4. People who work with animals should pay as much attention as possible to the use of personal protective equipment, which will significantly reduce the risk of damage to health in the event of an accident.

\section{REFERENCES}

1.Felczykowska A, Lipińska B, Pragacz M, Sadowska H, ŻeromskaMielniczuk D. Wypadki przy pracy w 2018 r. Informacje statystyczne 2019. Główny Urząd Statystyczny. https://stat.gov.pl/obszarytematyczne/rynek-pracy/warunki-pracy-wypadki-przy-pracy/ wypadki-przy-pracy-w-2018-roku,3,34.html.

2. Wypadki przy pracy i choroby zawodowe rolników oraz działania prewencyjne KRUS w 2019 roku. Kasa Rolniczego Ubezpieczenia Społecznego 2020. Opracowano w Biurze Prewencji na podstawie rocznych informacji i sprawozdań statystycznych Oddziałów Regionalnych KRUS. https://www.krus.gov.pl/zadania-krus/ prewencja/wypadki-przy-pracy-rolniczej/statystyka-wypadkow-wrolnictwie/2019/.

3. Singleton C, Manchella S, Nastri A. Operative management of equinerelated maxillofacial trauma presenting to a Melbourne level-one trauma centre over a six-year period. Br J Oral Maxillofac Surg. 2019 Dec; 57(10): 1126-1130. https://doi: 10.1016/j.bjoms.2019.10.301

4. Brown LH, Teixeira PG, Aydelotte JD, Coopwood TB, Trust MD, Ali $S$, Brown CVR. A national trauma data bank analysis of large animalrelated injuries. Injury. 2021; 52(9): 2677-2681. https:// doi: 10.1016/j. injury.2021.03.020

5. Tremelling AM, Marley RA, Marley MB, Woofter CM, Docherty C, Salvator AE, et al. Similarities between large animal-related and motor vehicle crash-related injuries. Wilderness Environ Med. 2017; 28(3): 213-18. https://doi: 10.1016/j.wem.2017. 05.004

6. Islam S, Gupta B, Taylor CJ, Chow J, Hoffman GR. Equine-associated maxillofacial injuries: retrospective 5-year analysis. Br J Oral Maxillofac Surg. 2014; 52(2): 124-7. https://doi: 10.1016/j.bjoms.2013.09.019

7. Onișor-Gligor F, Țenț PA, Bran S, Juncar M. A Naso-Orbito-Ethmoid (NOE) Fracture Associated with Bilateral Anterior and Posterior Frontal Sinus Wall Fractures Caused by a Horse Kick-Case Report and Short Literature Review. Medicina (Kaunas). 2019; 9: 55(11): 731. https:// doi: 10.3390/medicina55110731

8. Popoff MR. Tetanus in animals. J Vet Diagn Invest. 2020; 32(2): 184-191. https://doi: 10.1177/1040638720906814

9. Hryniewicz W, Ozorowski T. Rekomendacje diagnostyki, terapii i profilaktyki antybiotykowej zakażeń w szpitalu. Wydawnictwo sfinansowane ze środków będących w dyspozycji Ministra Zdrowia w ramach programu zdrowotnego pn.: „Narodowy Program Ochrony Antybiotyków na lata 2011-2015". ISBN 978-83-938000-2-5

10. Żukowska A, Hryniewicz W. Rekomendacje diagnostyki, terapii i profilaktyki antybiotykowej, zakażeń w szpitalu - 2020. Materiał przeznaczony dla komitetów terapeutycznych i zespołów ds. antybiotykoterapii. Wydawnictwo sfinansowane ze środków będących w dyspozycji Ministra Zdrowia w ramach programu zdrowotnego pn.: „Narodowy Program Ochrony Antybiotyków na lata 2016-2020”. ISBN 978-83-949636-3-7 